\title{
Efficiency of the silicate pump at a coastal oligotrophic site in the Mediterranean Sea
}

\author{
K. Leblanc ${ }^{1}$, B. Quéguiner ${ }^{2}$, P. Raimbault ${ }^{2}$, and N. Garcia ${ }^{2}$ \\ ${ }^{1}$ College of Marine Studies, University of Delaware, 700 Pilottown Road, Lewes, DE 19958, USA \\ ${ }^{2}$ Laboratoire d'Océanographie et de Biogéochimie, CNRS, University of Aix-Marseille II, Campus de Luminy, 13288 \\ Marseille Cedex 9, France
}

Received: 31 March 2005 - Published in Biogeosciences Discussions: 9 May 2005

Revised: 15 August 2005 - Accepted: 16 August 2005 - Published: 29 August 2005

\begin{abstract}
A one-year survey of the sedimenting particulate material was conducted at the SOFi site located on the edge of the continental slope in the Gulf of Lions (Northwestern Mediterranean) between September 1999 and December 2000. The main focus of this paper was to establish an annual budget of biogenic silica export, to describe the seasonnal pattern of Si fluxes in relation to the organic and mineral C fluxes and to quantify the $\mathrm{Si} / \mathrm{C}$ decoupling processes during sedimentation. The pattern of the downward flux of BSi was partly typical with increased daily sedimentation rates during spring followed by smaller peaks during summer. However, an unusual sedimentation event was recorded in the bottom trap in February before the spring thermal stratification occurred, and represented $37 \%$ of the annual BSi mass flux. The total annual BSi flux at the SOFi site was estimated from the bottom trap and amounted to $86.8 \mathrm{mmol} \mathrm{Si} \mathrm{m}^{-2} \mathrm{y}^{-1}$, while the organic carbon flux amounted to $154.9 \mathrm{mmol} \mathrm{C}$ $\mathrm{m}^{-2} \mathrm{y}^{-1}$. The overall efficiency of $\mathrm{C}$ export to depth compared to surface primary production budgets was low (3\%) and similar to values found for oligotrophic regions of the Eastern Mediterranean. On the other hand, we documented a very high efficiency of the Si export at the SOFi site, with $62 \%$ of the Si produced in the surface layer exported to the bottom trap. The excellent correlation between BSi and particulate organic $\mathrm{C}$ (POC) in the bottom trap further indicates that the bulk of the organic matter is transferred to depth in association with diatoms. However, the main fraction of the $\mathrm{C}$ produced by phytoplankton is lost in the water column through oxidation or metabolisation, while biogenic silica is more efficiently transferred to depth. This strong $\mathrm{Si} / \mathrm{C}$ decoupling with depth is likely to be the cause of the spring
\end{abstract}

Correspondence to: K. Leblanc

(leblanc@com.univ-mrs.fr) depletion of silicic acid over the entire water column which was observed by mid-April in a companion study (Leblanc et al., 2003) and may cause a severe Si limitation of the diatom spring bloom in this oligotrophic region of the Gulf of Lions.

\section{Introduction}

Even though continental margins represent only $8 \%$ of the ocean surface, they are the sites of high marine organic productivity and contribute to between 18 and $33 \%$ of total oceanic C production (Wollast, 1991). Due to their shallow depths, they are also the sites of enhanced $\mathrm{C}$ burial in the sediments with a burial rate 10 to 100 times higher than the oceanic domain (Berger et al., 1989). Liu et al. (2001) estimated the total $\mathrm{C}$ burial rate in the continental margins to be $0.15 \times 10^{15} \mathrm{~g} \mathrm{C} \mathrm{y}^{-1}$, which would represent two-thirds of the total oceanic burial. Understanding the biological and physical processes driving the export of organic material in the coastal zones is thus crucial to a better characterization of these areas as sinks or sources of $\mathrm{C}$.

A number of studies have focused on the $\mathrm{C}, \mathrm{N}, \mathrm{P}$ budgets of these coastal zones while much fewer have addressed the Si cycle. Diatoms are known to dominate in nutrient rich and highly turbulent areas and are therefore largely represented in coastal environments (Margalef, 1978). They are often associated with massive spring blooms followed by subsequent rapid sedimentation, resulting in stronger $\mathrm{C}$ export to depth as compared to the development of a microbial loop, which favors $\mathrm{C}$ recycling within the photic layer (Legendre and Lefèvre, 1989). The opal burial was first thought to occur primarily in the Southern Ocean, below the Polar Front belt, where sediments are almost entirely composed of

(C) 2005 Author(s). This work is licensed under a Creative Commons License. 


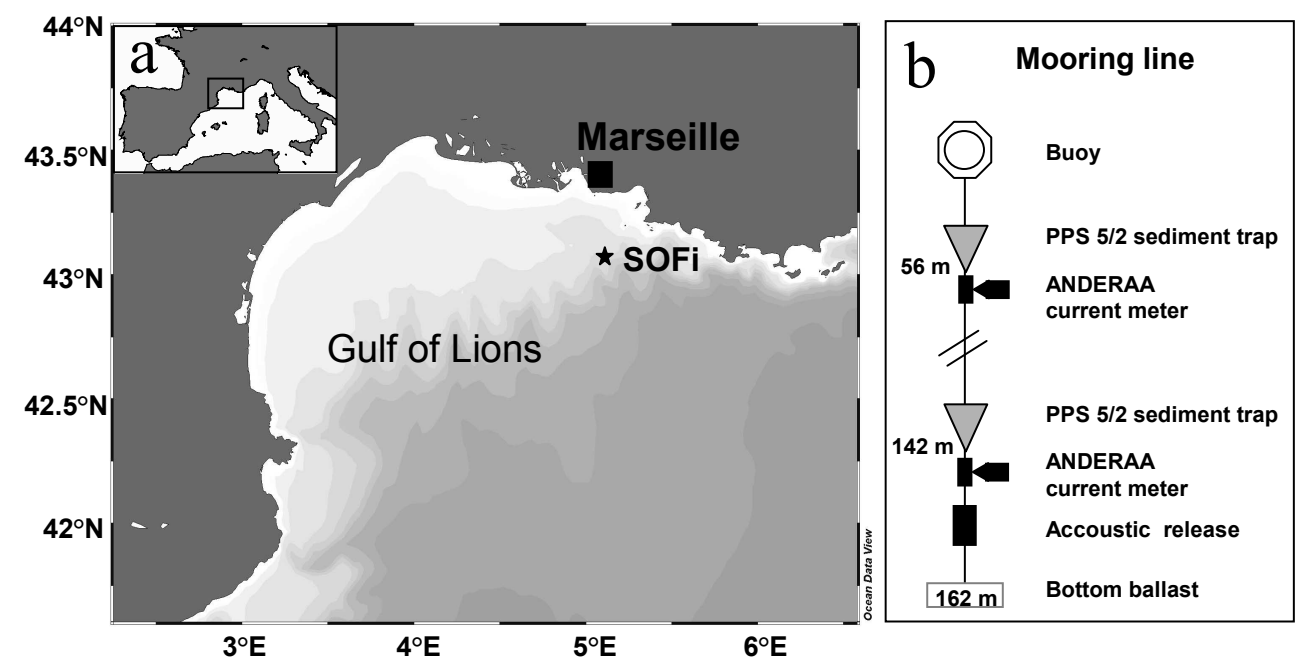

Fig. 1. (a) Study site location, (b) Schematic of the mooring line.

diatomaceous opal, and led to a previous estimates that $2 / 3$ of the global burial of biogenic silica took place in this region (DeMaster, 1981; Tréguer et al., 1995). Recent studies evidenced that the opal burial rate in the Southern Ocean has been largely overestimated due to sediment focusing, and reestablished the budget of this region to a 17 to $37 \%$ contribution to the global opal burial (Pondaven et al., 2000; Ragueneau et al., 2000). The "lost" Si burial in the Southern Ocean is thought to be balanced by the a higher export rate on continental margins. New estimates indicate that the Si burial for the continental margins amounts to 32 to $39 \%$ of the total burial, leading to a reasonable balance of the global Si budget (Ragueneau et al., 2000).

In the Mediterranean Sea, the Si cycle is overall poorly documented compared to the available studies on $\mathrm{C}, \mathrm{N}$ and $\mathrm{P}$. In the present study, we have focused on the Si cycle and on opal fluxes throughout a yearly survey in the Gulf of Lions, located on the French Mediterranean coast. The long-term observation site SOFi (Site d'Observation FIxe) has been the object of a seasonal study since 1997. From September 1999 to November 2000, we conducted additional measurements describing the silicon cycle. A companion paper published in a special issue dedicated to the Gulf of Lions describes the seasonal pattern of diatom distribution and biogenic silica production in the water column (Leblanc et al., 2003). In the present paper, complementary data characterizing the downward fluxes of particulate matter and biogenic silica in sediment traps are further presented. The aim of this study was to establish an annual budget of biogenic silica export at the SOFi site and in particular: to describe the annual Si flux patterns, to compare them with the other constituents of the downward flux such as particulate organic and inorganic carbon (POC and calcium carbonate, $\mathrm{CaCO}_{3}$ ) and finally to address the $\mathrm{Si} / \mathrm{C}$ decoupling processes during the sedimentation.

\section{Material and methods}

The study site (depth $162 \mathrm{~m}$ ) was located in the Gulf of Lions in the North Western Mediterranean Sea $\left(5^{\circ} 07^{\prime} 60 \mathrm{E}\right.$; $43^{\circ} 04^{\prime} 00 \mathrm{~N}$ ) on the edge of the continental slope 20 miles off Marseille (Fig. 1a). The sedimenting particulate matter was collected between September 1999 and November 2000 by a mooring line equipped with two sediment traps (Technicap ${ }^{\circledR}$ PPS 5/2, collection area $1 \mathrm{~m}^{2}, 24$ receiving cups), located at $56 \mathrm{~m}$ and $142 \mathrm{~m}$ depth, $20 \mathrm{~m}$ above bottom (Fig. 1b). The cups were filled before deployment with filtered seawater $(0.45 \mu \mathrm{m})$ containing $5 \%(\mathrm{v} / \mathrm{v})$ buffered formaldehyde for sample preservation. The sediment trap sampling interval was set at 3-4 days in order to catch any short scale sedimentation pulse, while trap contents were retrieved every three months. The samples were stored in the dark at $4^{\circ} \mathrm{C}$ and were processed at the laboratory a day after recovery for total mass flux and particulate carbon.

Large swimmers were removed using a $200 \mu \mathrm{m}$ mesh, and any remaining ones were removed manually. Sub-samples were then filtered onto GF/F Whatman filters $(0.2 \mu \mathrm{m})$, rinsed with deionised water and oven-dried at $60^{\circ} \mathrm{C}$. Total carbon was analyzed by combustion on a CHN carbon analyzer (LECO 800) according to Raimbault et al. (1999). A replicate sample was then calcinated to remove the organic $\mathrm{C}$ content and analyzed for particulate mineral carbon $\left(\mathrm{CaCO}_{3}\right)$ on the CHN. Particulate organic carbon (POC) was calculated by substraction of the two measurements $(\mathrm{POC}=$ total $\mathrm{C}$-mineral C). Calcium carbonate was calculated by using the inorganic carbon $\left(\mathrm{CaCO}_{3}=\right.$ inorganic carbon $\left.\times 100 / 12\right)$.

A known volume was sub-sampled for biogenic silica (BSi) determination, and the sediment material was freezedried after centrifugation and removal of the supernatant. An optimal quantity of $5 \mathrm{mg}$ dry sediment was determined for the BSi measurement. Pre-treatment assays showed a better 


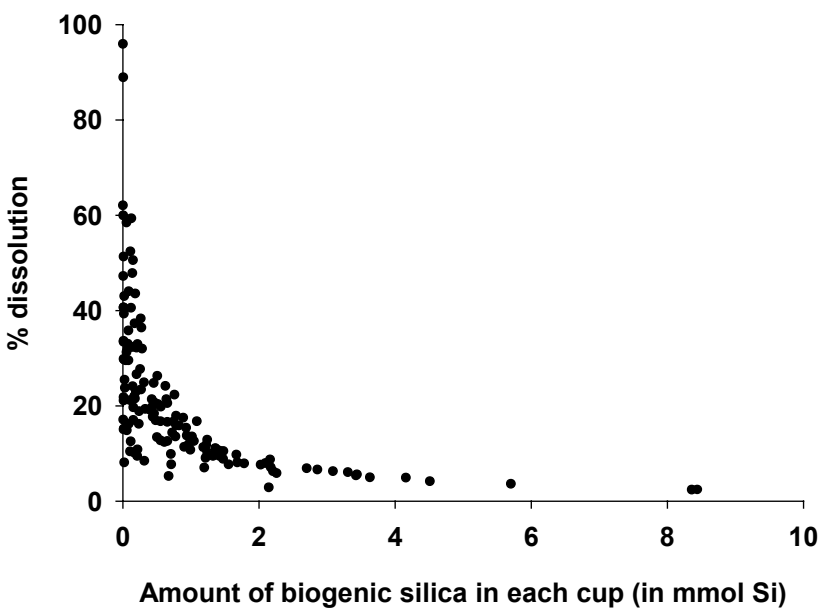

Fig. 2. Percentage of the dissolved silicon fraction (from silicic acid measurements) in each sediment cup compared to the total particulate amount of biogenic silica.

extraction efficiency when samples were treated with $10 \%$ $\mathrm{H}_{2} \mathrm{O}_{2}$ for 30 min. followed by an exposition to concentrated $\mathrm{HCl}$ fumes for $24 \mathrm{~h}$. The acid-treated dry sediment was placed in a $50 \mathrm{~mL}$ centrifuge tube and $\mathrm{BSi}$ was extracted in $40 \mathrm{~mL} \mathrm{NaOH}(0.2 \mathrm{~N})$ at $95^{\circ} \mathrm{C}$ for $2 \mathrm{~h}$ according to Kamatani and Oku (2000). At T0+20, 40, 60, 90 and $120 \mathrm{~min}$. during the extraction, two sub-samples of $200 \mu \mathrm{L}$ were respectively analyzed for dissolved silica and aluminum (Al). Al measurements were used to discriminate between biogenic and lithogenic silica, since lithogenic minerals usually have a mean $\mathrm{Si} / \mathrm{Al}$ ratio of 2, while $\mathrm{Al}$ incorporation in diatom frustules is negligible (Kamatani, 1974). Dissolved Al was measured on an ICP-AES in Brest (courtesy of J. Cotten, IUEM, Brest) but concentrations remained under the detection limit (2 ppb), indicating the absence of contaminating LSi. Biogenic silica was therefore estimated following DeMaster (1981), by plotting dissolved silica vs. time and calculating the intercept on the $y$-axis of the tangent to the linear part of the extraction curve. When there was no consistent increasing trend in extracted $\mathrm{Si}$ with time, $\mathrm{BSi}$ was calculated as the mean concentration of the 3 last measurements (Conley, 1998). Corrections were made to include the amount of BSi that had dissolved in the cups during sampling and storage by measuring $\mathrm{Si}(\mathrm{OH})_{4}$ in the supernatant immediately before freeze-drying the sediment trap material. Si dissolution in the cups decreased exponentially with the amount of biogenic silica present in each sample (Fig. 2). Considering $\mathrm{Si}$ dissolution in the collection cups resulted in a correction of the annual BSi flux at the SOFi site of $+9.5 \%$ and should therefore systematically be taken into account.

Sediment cores were sampled between April and September 2000 during the monthly survey of the SOFi site (Leblanc et al., 2003) and the BSi content of the $0-0.5 \mathrm{~cm}$ surface layer of the sediment was measured following the protocol for sed-

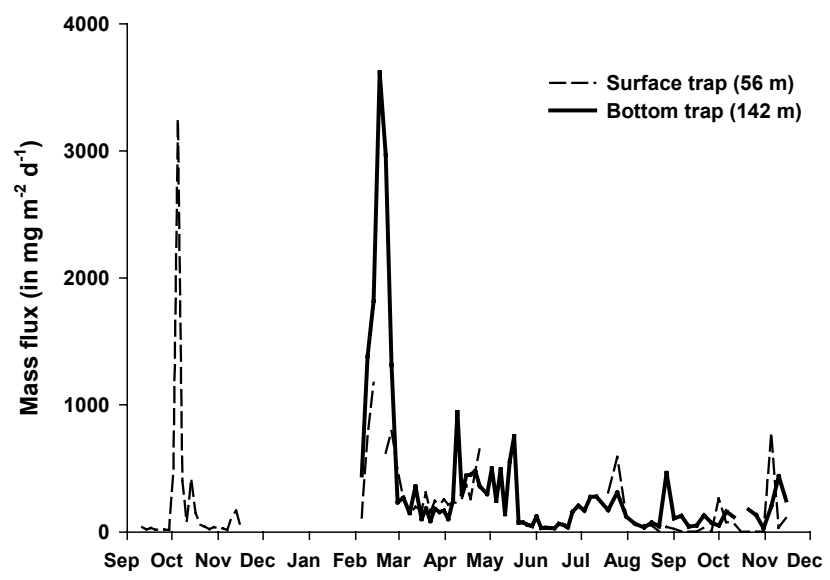

Fig. 3. Total mass flux in $\mathrm{mg} \mathrm{m}^{-2} \mathrm{~d}^{-1}$ of dry weight in the surface trap $(56 \mathrm{~m})$ and the bottom trap $(142 \mathrm{~m})$ throughout the survey (1999-2000).

iment traps described above. Si fluxes are expressed as opal as described in Mortlock and Froelich (1989) for better comparison with other studies (opal=biogenic silica $\times 2.4$ ).

\section{Results}

Sediment traps were deployed and recovered on average every ten weeks, but due to a technical failure of the motors rotating the sampling cups, both the surface and deep series were interrupted. The mooring line was furthermore not deployed between November 1999 and February 2000, due to ship immobilization. Bottom and surface trap results will be compared when feasible, but we will mainly focus on the lower trap data, which provides the longest continuous series.

\subsection{Mass fluxes}

Mass fluxes were recorded at $56 \mathrm{~m}$ and $142 \mathrm{~m}$ between September 1999 and December 2000 (Fig. 3). During the sampling period, the mass fluxes at the SOFi site remained low most of the time, exceeding $1000 \mathrm{mg} \mathrm{m}^{-2} \mathrm{~d}^{-1}$ only on three occasions. Throughout the survey, the mean total mass fluxes were 239 and $350 \mathrm{mg} \mathrm{m}^{-2} \mathrm{~d}^{-1}$ in the surface and bottom traps, respectively. Higher variability in the daily mass fluxes was observed in the deeper trap (standard deviation between all samples $\pm 600 \mathrm{mg} \mathrm{m}^{-2} \mathrm{~d}^{-1}$ ) as compared to the upper one $\left( \pm 437 \mathrm{mg} \mathrm{m}^{-2} \mathrm{~d}^{-1}\right)$. At $56 \mathrm{~m}$ depth, fluxes varied from 1 to $3249 \mathrm{mg} \mathrm{m}^{-2} \mathrm{~d}^{-1}$ while fluxes recorded at $142 \mathrm{~m}$ ranged between 28 and $3617 \mathrm{mg} \mathrm{m}^{-2} \mathrm{~d}^{-1}$. The highest mass flux was recorded in mid-February 2000 at $142 \mathrm{~m}$, while the flux at $56 \mathrm{~m}$ was approximately 3 times lower. The most important sedimentation event sampled in the surface trap occurred in the beginning of October 1999. As a general trend, surface and deep mass fluxes appeared uncorrelated. 


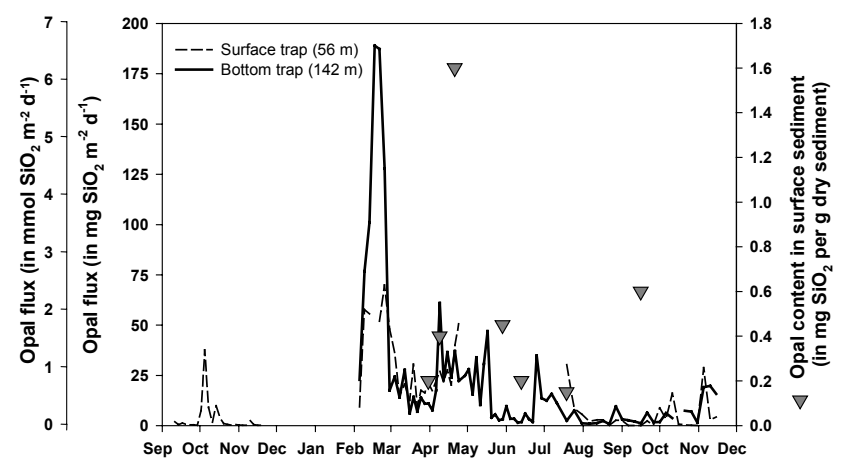

Fig. 4. Left axis: opal flux in $\mathrm{mg} \mathrm{m}^{-2} \mathrm{~d}^{-1}$ and $\mathrm{mmol} \mathrm{m} \mathrm{m}^{-2} \mathrm{~d}^{-1}$ in the surface trap $(56 \mathrm{~m})$ and the bottom trap $(142 \mathrm{~m})$ throughout the year. Right axis (triangles): opal content of the sediment surface layer in $\mathrm{mg}$ Si per $\mathrm{g}$ dry sediment.

\subsection{Opal fluxes}

Similarly to the mass fluxes, biogenic silica or opal fluxes were generally higher in the lower trap (mean: $21.6 \pm 36.1 \mathrm{mg}$ opal m $\mathrm{m}^{-2} \mathrm{~d}^{-1}$ ) than in the surface trap (mean: $12.8 \pm 17.0 \mathrm{mg}$ opal m $\mathrm{m}^{-2} \mathrm{~d}^{-1}$ ) (Fig. 4). Opal fluxes presented one major increase in mid-February 2000 in the deeper trap (189.1 $\mathrm{mg} \mathrm{opal} \mathrm{m}^{-2} \mathrm{~d}^{-1}$ ) while smaller sedimentation peaks were recorded between April and mid-May. In the surface trap, the highest opal flux was observed towards the end of February (69.1 mg opal m $\mathrm{m}^{-2} \mathrm{~d}^{-1}$ ). Opal fluxes and mass fluxes appeared significantly correlated in both traps (upper trap: $r^{2}=0.73, v=69$; lower trap: $r^{2}=0.94, v=71$ ).

The biogenic silica content was measured in surface sediments $(0-0.5 \mathrm{~cm}$ layer) on 7 occasions during the monthly survey of the SOFi site (Fig. 4). The sediment silica content increased significantly at the end of April with $3.8 \mathrm{mg}$ opal $\mathrm{g}^{-1}$ dry sediment, whereas the average value for the 6 other measurements was $0.8 \pm 0.4 \mathrm{mg}$ opal g ${ }^{-1}$ dry sediment.

\subsection{Particulate organic carbon (POC) fluxes}

Particulate carbon fluxes patterns showed some similarities with the precedent parameters, with peaks of sedimentation occurring at the same periods, but of varying intensity (Fig. 5). Contrarily to BSi and total mass flux which increased in the bottom trap, the average POC fluxes over the sampling period were very similar in both traps, with $26.3 \pm 30.5 \mathrm{mg} \mathrm{C} \mathrm{m}^{-2} \mathrm{~d}^{-1}$ at $56 \mathrm{~m}$ and $24.3 \pm 35.3 \mathrm{mg} \mathrm{C} \mathrm{m}^{-2} \mathrm{~d}^{-1}$ at $142 \mathrm{~m}$. The largest sedimentation events were recorded in the beginning of October 1999 in the surface trap $\left(169.9 \mathrm{mg} \mathrm{C} \mathrm{m}^{-2} \mathrm{~d}^{-1}\right.$ and in mid-February 2000 in the bottom trap $\left(195.1 \mathrm{mg} \mathrm{C} \mathrm{m}^{-2} \mathrm{~d}^{-1}\right)$.

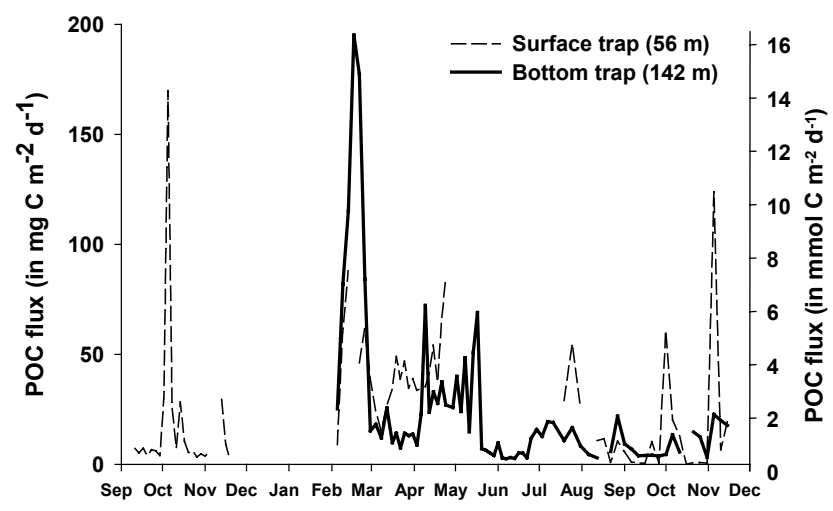

Fig. 5. Particulate Organic Carbon (POC) flux in $\mathrm{mg} \mathrm{m}^{-2} \mathrm{~d}^{-1}$ and in $\mathrm{mmol} \mathrm{m} \mathrm{m}^{-2} \mathrm{~d}^{-1}$ in the surface trap $(56 \mathrm{~m})$ and the bottom trap $(142 \mathrm{~m})$ throughout the year.

\subsection{Calcium carbonate flux}

The surface trap recorded several calcium carbonate sedimentation events occurring mainly during the fall season and the end of summer (August to December months), ranging from 95.0 to $575.4 \mathrm{mg} \mathrm{CaCO}_{3} \mathrm{~m}^{-2} \mathrm{~d}^{-1}$ (Fig. 6). By comparison the early spring flux of carbonate recorded in February 2000 was slightly lower and ranged from 180.4 to $195.1 \mathrm{mg}$ $\mathrm{CaCO}_{3} \mathrm{~m}^{-2} \mathrm{~d}^{-1}$. In the bottom trap, the highest flux was observed in February 2000 (746.7 $\mathrm{mg} \mathrm{CaCO}_{3} \mathrm{~m}^{-2} \mathrm{~d}^{-1}$ ), coinciding with the increase described for all other parameters. The average carbonate flux over the entire survey was fairly similar in both traps, with an average of $65.0 \pm 97.7 \mathrm{mg}$ $\mathrm{CaCO}_{3} \mathrm{~m}^{-2} \mathrm{~d}^{-1}$ in the surface trap and of $73.7 \pm 126.7 \mathrm{mg}$ $\mathrm{CaCO}_{3} \mathrm{~m}^{-2} \mathrm{~d}^{-1}$ in the bottom trap.

\section{5 $\mathrm{Si} / \mathrm{C}$ ratio of sedimenting particles}

The Si:C molar ratios of sedimented particulate matter were calculated for both trap samples and compared to the ratio for living diatoms of 0.09-0.13 (Brzezinski, 1985) (Fig. 7). $\mathrm{Si}$ C ratios were generally lower in the surface trap (average $\mathrm{BSi}: \mathrm{POC}=0.09)$ and increased substantially in the bottom trap (average $\mathrm{BSi} / \mathrm{POC}=0.14$ ). A sharp increase of the Si:C molar ratio was observed in mid-October 2000 at $56 \mathrm{~m}$, with a peak value of 1.03. In the bottom trap samples, the highest ratio was recorded at the end of June, when the Si:C ratio reached 0.52 .

The opal and POC fluxes appeared significantly correlated at both depth (at $56 \mathrm{~m} r^{2}=0.51, \alpha=0.001, \nu=68$ and at $142 \mathrm{~m}$ $\left.r^{2}=0.95, \alpha=0.001, v=70\right)$ as shown in Fig. 8. The slope of the regression line, representing the average BSi:POC ratio, was again lower at $56 \mathrm{~m}$ than at $142 \mathrm{~m}(0.07$ vs. 0.18$)$.

\section{6 $\mathrm{Si}$ and $\mathrm{C}$ export budgets}

The annual Si export budget for the year 2000 was estimated from the bottom trap, which provided the longest continuous 


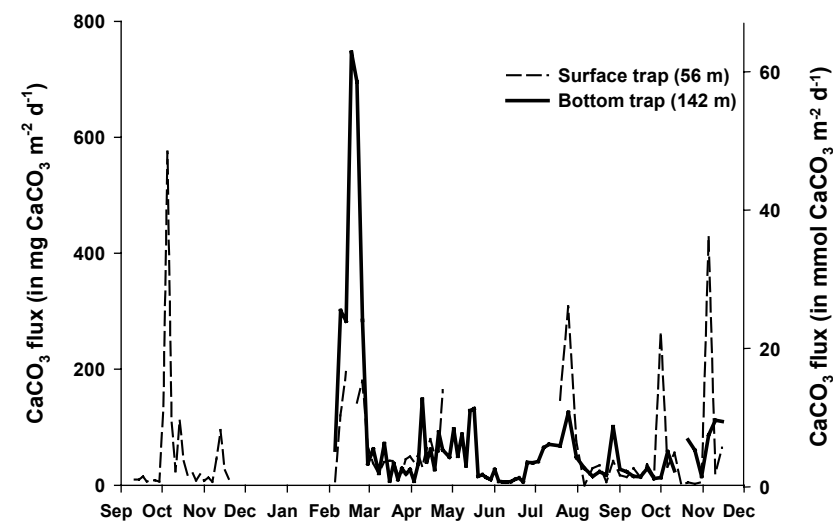

Fig. 6. Calcium carbonate $\left(\mathrm{CaCO}_{3}\right)$ flux in $\mathrm{mg} \mathrm{m}^{-2} \mathrm{~d}^{-1}$ and in mmol m $\mathrm{m}^{-2} \mathrm{~d}^{-1}$ in the surface trap $(56 \mathrm{~m})$ and the bottom trap $(142 \mathrm{~m})$ throughout the year.

data set. The surface trap was furthermore not positioned deeply enough to take into account all biological processes occurring over the entire photic zone. Two main sampling gaps were observed for the bottom trap (from 1 January to 5 February and from 15 November to 31 December) corresponding to winter periods when the biogenic Si flux is negligible. The Si flux for these periods has therefore been extrapolated from the average Si flux obtained from 1 September to 15 November period, when downward Si fluxes were homogeneous and low. The annual opal flux amounted to $5831 \mathrm{mg} \mathrm{m}^{-2} \mathrm{y}^{-1}$, corresponding to an average daily flux of $16 \mathrm{mg} \mathrm{m}^{-2} \mathrm{~d}^{-1}$. The same calculation was applied to the POC flux and resulted in an annual organic C flux of 2082 $\mathrm{mg} \mathrm{m}^{-2} \mathrm{y}^{-1}\left(5.7 \mathrm{mg} \mathrm{m}^{-2} \mathrm{~d}^{-1}\right)$.

\section{Discussion}

\subsection{Total sedimentation fluxes}

The total mass flux was overall low $\left(<1000 \mathrm{mg} \mathrm{m}^{-2} \mathrm{~d}^{-1}\right)$ throughout the survey, except for two sedimentation events exceeding $3000 \mathrm{mg} \mathrm{m}^{-2} \mathrm{~d}^{-1}$. These fluxes were similar to values recorded in the Cretan Sea (Stavrakakis et al., 2000) and reflect the oligotrophic nature of the North Mediterranean Current (NMC) which flows along the slope during most of the year. A similar range of mass fluxes was observed by Monaco et al. (1999) in the Grand Rhône Canyon, situated just west of the SOFi site, with fluxes comprised between 80 and $3410 \mathrm{mg} \mathrm{m}^{-2} \mathrm{~d}^{-1}$. As a general trend, one could also note an average increase of $30 \%$ of the mass flux from the surface trap to the bottom trap, which is the reverse of what is commonly observed in the open ocean, where the sedimenting flux rapidly decreases with depth. This phenomenon has already been described for the Gulf of Lions (Monaco et al., 1990; Kerhervé et al., 2001) and several other locations

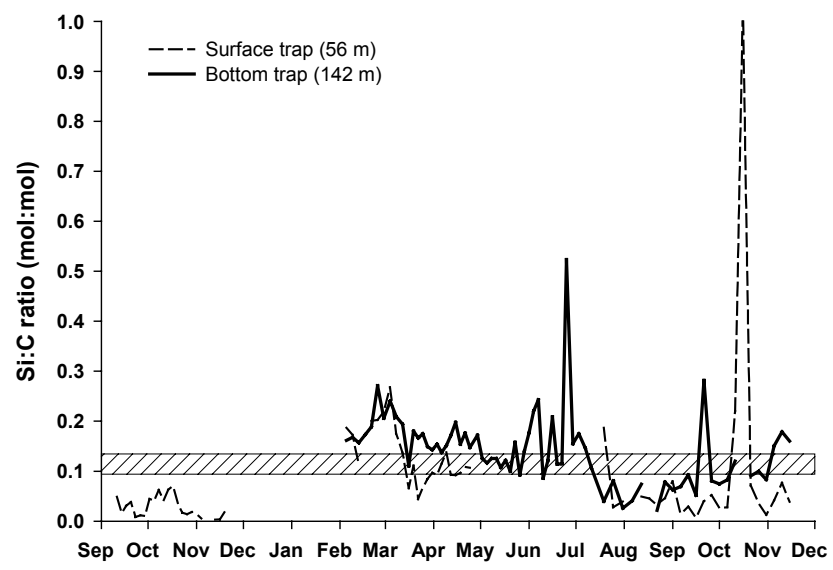

Fig. 7. $\mathrm{Si}: \mathrm{C}$ molar ratios of the settling material in the surface trap $(56 \mathrm{~m})$ and the bottom trap $(142 \mathrm{~m})$ throughout the year. The shaded area represents the commonly used ratios of $0.09-0.13$ characterizing live diatoms (Brzezinski, 1985).

on the continental margins and has been attributed to sediment resuspension events (Gardner et al., 1983; Auffret et al., 1994), lateral transport (Heussner et al., 1999; Stavrakakis et al., 2000) or the presence of bottom nepheloid layers carrying a strong load of allochtonous fresh material (Monaco et al., 1990; Miserrochi et al., 1999). The shallow depth of the surface trap could further not explain this increase in mass flux in the bottom sediment trap, as a cut-off at $56 \mathrm{~m}$ rather than the bottom of the euphotic layer induces only a small decrease in the yearly integrated primary production $(-8.5 \%)$ or Si uptake rates $(-16 \%)$.

Furthermore, the correlation coefficients between the biogenic components and the total mass fluxes increased between the surface and bottom traps, confirming that more biogenic material was collected by the deeper trap than by the surface one. At $56 \mathrm{~m}$, the correlation coefficients between the daily mass flux and daily fluxes of $\mathrm{POC}$, opal and $\mathrm{CaCO}_{3}$ were respectively $0.77,0.37$ and 0.73 . At $142 \mathrm{~m}$, these same coefficients increased to $0.97,0.95$ and 0.96 , respectively. It follows that the biogenic components varied concomitantly with the total mass flux throughout the survey.

\subsection{Temporal variability and seasonality}

The seasonal pattern was partly typical, with an increase of the mass flux during the productive spring season, followed by several other sedimentation peaks scattered in the summer and autumn. However, a highly atypical event also occurred towards the end of winter, before the thermal spring stratification of the surface layer (Leblanc et al., 2003). Indeed, an important sedimentation peak was recorded at both depths in mid-February, with a total mass flux more than 3 times higher than the spring peak value, which was reflected similarly by the strongest annual increase in organic carbon, opal and calcium carbonate fluxes. Likely explanations for 

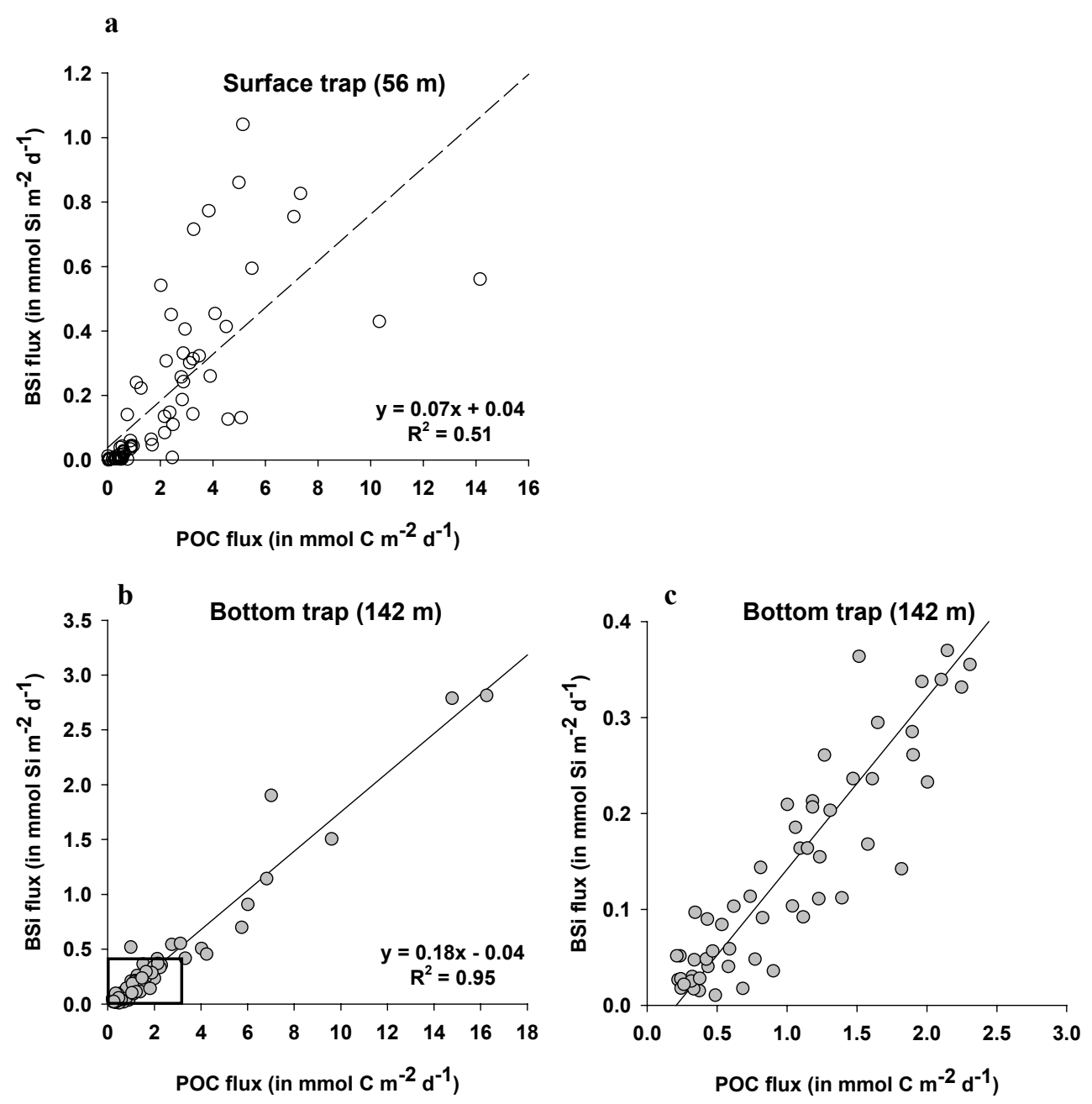

Fig. 8. Correlations between the POC and BSi molar fluxes for in (a) the surface trap (56 m) and (b) the bottom trap (142 m) for all available paired data. Pannel (c) represents the same data as pannel (d) but the axis scales were reduced to better visualize the regression at low concentrations.

this increased flux could have been the occurrence of a large sediment resuspension event due to the strong hydronamic forcing observed in the winter season in the Gulf of Lions or to the capture of a nepheloid bottom layer originating from the plateau. Both explanations were ruled out for several reasons. Firstly, this large downward flux was also seen in the surface trap, which is not likely to receive any inputs from resuspended sediments. Secondarily the microscopic examination of preserved trap samples evidenced the presence of large quantities of fresh pelagic material, constituted primarily of very large solitary diatoms, such as Dytilum brightwelli $(500 \mu \mathrm{m})$, Thalassionema sp. $(500 \mu \mathrm{m})$, Bidulphia mobiliensis $(100 \mu \mathrm{m})$, Coscinodiscus sp. $(>100 \mu \mathrm{m})$, as well as of chain forming diatoms such as Chaetoceros $s p$., together with an important amount of organic debris and fecal pellets (Fig. 9), ruling out a benthic origin for this material. The opal flux in mid-February constituted as much as $36 \%$ of the annual flux of biogenic opal at the SOFi site in the bottom trap. We hypothesize that this event was either the result of strong lateral advection of pelagic material originating from the plateau and exported towards the slope under strong NW winds recorded in early February, or the result of a brief but intense precocious bloom event on the continental margin slope. Unfortunately, the monthly cruises conducted to survey the biological production at the SOFi site for that period were carried before and after the event (5 February and $30 \mathrm{March}$ ) and did not detect this early diatom bloom in the water column (Leblanc et al., 2003). This type of transient and intense phytoplankton growth is expected to occur frequently in the Gulf of Lions, where highly turbulent periods resulting in an entirely homogeneous and nutrient replenished water column can be followed by periods of calm winds and strong solar radiation.

The spring bloom was reflected in both traps from midFebruary to mid-May, when the largest biological signal was observed and trap data showed a significant increase of the 

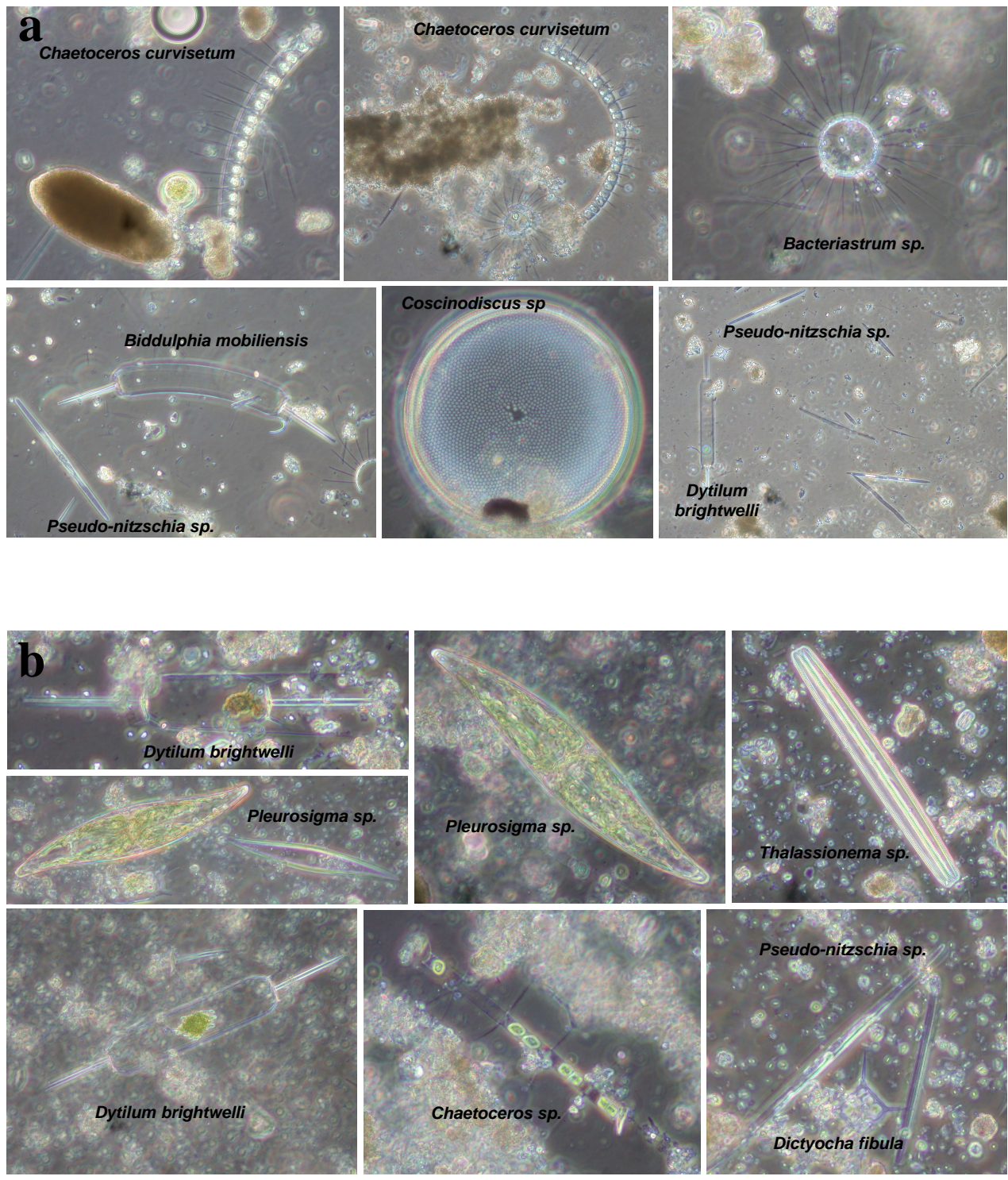

Fig. 9. (a) Photographs of the content of the collecting cup at $56 \mathrm{~m}$ on 25 February 2000, when the largest peak of opal was recorded. The sample was primarily constituted of Chaetoceros sp. chains and large Coscinodiscus sp. (b) Photographs of the content of the collecting cup at $142 \mathrm{~m}$ on 17 February 2000, when the largest peak of opal was recorded. The sample was primarily constituted of Dytilum brightwelli, Pleurosigma sp. and Thalassionema sp.

downward flux of all components during that period. The diatom spring bloom was also recorded in the sediment, with an increase of the opal content of the surface sediment by a factor 4 on 21 April. The Si flux in April represented 17\% of the total annual flux estimated from the bottom trap.

By comparison with the monthly water column survey, it appears that the monthly and even bi-monthly sampling intervals during spring was not adequate to cover the full extent of the productive season. The present sediment trap data indicate that the water column biogenic silica as well as the $\mathrm{Si}$ production rates measured in situ are likely to be underestimated for the SOFi site (Leblanc et al., 2003) and that the downward material flux occurs with a high temporal variabil- ity, which can be seen as short pulses of sedimentation and drastic flux increases over only a few days. This short-term variability has been described in previous studies as the result of several forcing events such as the Rhône River inputs, the strong wind regimes in the Gulf of Lions, internal waves, resuspension events, variations of the path of the NMC (Millot, 1990) and rapid changes in the light and nutrient regimes, which allows phytoplankton to bloom outside of the productive period (Diaz et al., 2000). Thus a rotation period of the sediment trap cups of 3 to 4 days seems to be close to the minimum interval required to accurately accurately monitor the pulse-like biological events taking place in the Gulf of Lions. 


\section{$4.3 \mathrm{Si} / \mathrm{C}$ decoupling}

Opal and POC fluxes appeared overall well correlated, with concomitant export peaks, but of varying intensities depending on the nature of the phytoplankton community. The higher Si:C molar ratio confirmed the dominance of diatoms during the spring season, with fresh material ratios (comprised between 0.09 and 0.13 ) in the surface trap and increasing ratios closer to 0.2 in the bottom trap, reflecting the faster recycling of $\mathrm{C}$ in the water column compared to Si (Fig. 7). Diatom abundance decreased strongly under the autumnal oligotrophic conditions and $\mathrm{Si}: \mathrm{C}$ ratios decreased to values as low as 0.04 in the surface trap. The peak values of 1.03 measured in mid-October in the surface trap was not attributed to a sudden diatom bloom, but was the consequence of very low POC fluxes. Another peak in the Si:C ratio was observed in June (up to 0.5 ) and reflected a more detrital siliceous population remaining after the productive spring season.

The excellent correlation of BSi and POC fluxes in the bottom trap $\left(r^{2}=0.95\right)$ indicated that the largest fraction of the organic $\mathrm{C}$ exported to depth was associated to diatom sedimentation events, while smaller cells were more rapidly recycled within the euphotic layer (Fig. 8). Diatoms are known to form large aggregates characterized by high sedimentation rates, a process which efficiently transfers organic material to depth (Smetacek, 1985). However, the rapid increase of $\mathrm{Si}: \mathrm{C}$ ratios with depth illustrates the faster recycling of $\mathrm{C}$ as the microbial component remineralizes the sedimenting material and as zooplanktonic grazers preferentially metabolize $\mathrm{C}$ while excreting unusable particulate $\mathrm{Si}$ in fecal pellets. The decoupling of $\mathrm{Si}$ and $\mathrm{C}$ was apparent from the production ratio in the photic layer to the subsequent export to depth. The annual integrated Si:C production ratio, derived from Leblanc et al. (2003), was estimated to be 0.03 $\left(\Sigma \mathrm{Si} / \Sigma \mathrm{C}=0.14 \mathrm{~mol} \mathrm{Si} / 4.5 \mathrm{~mol} \mathrm{C} \mathrm{m}^{-2} \mathrm{y}^{-1}\right.$ ), which is similar to values found in the Equatorial Pacific (review in Ragueneau et al., 2000). Average annual Si:C export ratios increased to 0.09 at $56 \mathrm{~m}$ and 0.14 at $142 \mathrm{~m}$ and were comparable to those observed in other open ocean oligotrophic sites such as BATS and PAP (Ragueneau et al., 2002).

\subsection{Si and C budgets, efficiency of the silicate pump}

In the companion paper describing the biological processes occurring in the water column at the SOFi site, yearly Si and $\mathrm{C}$ production rate budgets were derived from monthly in situ measurements and amounted to $140 \mathrm{mmol} \mathrm{Si} \mathrm{m}^{-2} \mathrm{y}^{-1}$ and $4500 \mathrm{mmol} \mathrm{C} \mathrm{m}^{-2} \mathrm{y}^{-1}$ (Leblanc et al., 2003). The annual Si and $\mathrm{C}$ export flux budgets were estimated for the year 2000 from the bottom trap data, which presented the longest continuous dataset, using the following assumption: the low $\mathrm{Si}$ and $\mathrm{C}$ fluxes obtained from 1 September to 15 November 2000 were averaged to a daily flux and in turn extrapolated to the two gaps in the sample collection in January 2000 (36 days) and mid-November to December 2000 (46 days). The yearly estimates thus amounted to $86.8 \mathrm{mmol} \mathrm{Si} \mathrm{m}^{-2} \mathrm{y}^{-1}$ and $154.9 \mathrm{mmol} \mathrm{C} \mathrm{m}^{-2} \mathrm{y}^{-1}$. Thus the yearly export of biogenic silica to depth represents $62 \%$ of the Si produced in the water column, while only $3.4 \%$ of the annual C primary production reaches the same depth. The Si export efficiency may be close to the high range, since Si production budgets are likely to be underestimated at the SOFi site. These results emphasize the strong $\mathrm{Si} / \mathrm{C}$ decoupling that occurs when diatoms sediment through the water column. The preferential export of $\mathrm{Si}$ compared to $\mathrm{C}$ is well known and results in rapid loss of silicic acid in the surface layer during the productive season, which has been termed the "silicate pump" (Dugdale et al., 1995). The silicate pump seems particularly efficient at the SOFi site, with a rapid export of particulate Si to depth, and may explain together with the onset of stratification the complete depletion of the water column in silicic acid observed in April (Leblanc et al., 2003).

During the 1997-1999 survey at the SOFi site preceeding our study, Diaz (2000) found very similar C export rates in the sediment traps, with $8 \%$ of the $\mathrm{C}$ produced through primary production reaching the surface trap and $6 \%$ reaching the bottom trap, implying that the main fraction of organic $\mathrm{C}$ is lost through oxidation or metabolization. The efficiency of POC export to depth calculated for the SOFi site is consistent with values found in the literature for other oceanic systems (5 to 10\%) (Buesseler, 1998). In the Eastern Mediterranean, similar values were found, with an export efficiency of 2 to $3 \%$ of the primary production in the Cretan Sea (Stavrakakis et al., 2000) and less than $4 \%$ in the Adriatic (Boldrin et al., 2002). Another study conducted in different parts of the Mediterranean evidenced an increase in the $\mathrm{C}$ export efficiency from the Eastern (3\%) to the Western part (10\%) of the Mediterranean (Danovaro et al., 1999), but our results are more consistent with values found for the Eastern basin. This result was not surprising however, as oligotrophic conditions are prevalent at the SOFi site through out most of the year (Diaz, 2000; Leblanc et al., 2003).

\subsection{Si export fluxes - comparison with other studies}

A comparison with other annual Si export budget established for the Mediterranean Sea indicates that the annual flux at SOFi is similar in range to what has been observed in the Lacaze-Duthiers Canyon in the western part of the Gulf of Lions, but lower to the fluxes estimated from other studies conducted closer to our study site in the Eastern part of the Gulf (Table 1). Si export fluxes were at least twice as high at the exit of the Grand Rhône Canyon and on the open slope of the continental margin, which were located within 30 nautical miles of the SOFi site. This further emphasizes the strong temporal variability of sedimentation rates prevailing in the Gulf of Lions, which may in part be due to variations of the vertical component, driven by biological processes, but also to variations of the lateral transport from the continental 
Table 1. Comparison of sediment trap data of annual Si flux to depth in the Mediterranean Sea with the present study. GRC: Grand Rhône Canyon, LDC: Lacaze-Duthiers Canyon.

\begin{tabular}{|c|c|c|c|}
\hline & $\begin{array}{l}\text { Si flux } \\
\left(\mathrm{mmol} \mathrm{Si} \mathrm{m}{ }^{-2} \mathrm{y}^{-1}\right)\end{array}$ & $\begin{array}{l}\text { Depth } \\
(\mathrm{m})\end{array}$ & References \\
\hline \multicolumn{4}{|l|}{ Eastern Mediterranean } \\
\hline Cretan Sea & $3 ; 8$ & $200 ; 1515$ & Stavrakakis et al. (2000) \\
\hline Aegean Sea & 23 & 965 & Kerhervé et al. (1999) \\
\hline Ionian Sea & $17 ; 32$ & $880 ; 1345$ & Kerhervé et al. (1999) \\
\hline Ionian Sea & $46 ; 27$ & $150 ; 2250$ & Boldrin et al. (2002) \\
\hline Adriatic Bassin & $211 ; 327$ & $500 ; 1000$ & Miserocchi et al. (1999) \\
\hline Adriatic Bassin & $302 ; 420$ & $150 ; 1050$ & Boldrin et al. (2002) \\
\hline \multicolumn{4}{|l|}{ Western Mediterranean } \\
\hline Gulf of Lions - SOFi Site & 86.8 & 142 & This study \\
\hline Gulf of Lions - LDC & $32 ; 103 ; 163$ & $100 ; 300 ; 600$ & Monaco et al. (1990) \\
\hline Gulf of Lions - GRC & $147 ; 207$ & $80 ; 200$ & Monaco et al. (1999) \\
\hline Gulf of Lions - Open slope & 204 & 900 & Monaco et al. (1999) \\
\hline Alboran Sea - WAG & $345 ; 365$ & $400 ; 500$ & Fabres et al. (2002) \\
\hline Alboran Sea - WAG & $460 ; 338$ & $1000 ; 1300$ & Fabres et al. (2002) \\
\hline
\end{tabular}

shelf to the slope, which is likely to differ according to the bottom topography (Monaco et al., 1990). Si export fluxes at the SOFI site were also lower than the fluxes observed in the Adriatic Basin in the Eastern Mediterranean, but only twice as high as the Si fluxes in the Ionian Sea, which again demonstrates the presence of oligotrophic waters in this area. To our knowledge, the lowest Si fluxes in the Mediterranean were measured in the Cretan Sea, with annual fluxes as low as 3 to $8 \mathrm{mmol} \mathrm{Si} \mathrm{m}{ }^{-2} \mathrm{y}^{-1}$ (Table 1). The highest Si export was recorded in the Western Mediterranean in the Alboran

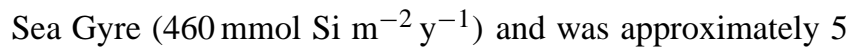
times higher than the flux measured at the SOFi site.

\section{Conclusions}

The downward particulate flux at the SOFi site showed a typical seasonal signal, with an increase of the total mass flux as well as of all biogenic components ( $\mathrm{POC}$, opal, $\mathrm{CaCO}_{3}$ ) during spring and several smaller peaks in summer and fall. However, the particulate flux also presented one atypical feature with the strongest opal flux (37\% of the annual budget) observed very early in the season in mid-February, before the spring thermal stratification of the water column even occurred. We hypothesize that a short-term bloom of diatoms may have taken place on the plateau and was subsequently advected towards the margin slope due to strong NW winds or that a brief but intense precocious bloom may have occurred locally.

The excellent correlation between biogenic silica and organic carbon in the bottom trap indicates that the bulk of the organic matter found in the bottom trap is transferred to depth in association with diatoms, which tend to sink more rapidly than other phytoplankton groups. However, the larger part of the organic $\mathrm{C}$ produced in the surface layer is remineralized in the water column before reaching the bottom trap, with an export efficiency of only $3 \%$. The silicate pump was on the other hand particularly efficient at the SOFi site, with $62 \%$ (high estimate) of the Si produced in the water column exported to depth. This decoupling of the $\mathrm{Si}$ and $\mathrm{C}$ cycles increased with depth, as seen in the increase of $\mathrm{Si} / \mathrm{C}$ ratios (0.09 to 0.14), reflecting the preferential preservation of $\mathrm{Si}$ over $\mathrm{C}$ during the sedimentation of particles.

The increased Si fluxes during spring were concomitant to a complete depletion of silicic acid throughout the water column by mid-April (Leblanc et al., 2003). Thus, the efficiency of the silicate pump in shallow systems of the continental margin may result in potential $\mathrm{Si}$ limitation conditions in the surface layer during the spring-summer season, preventing diatoms from forming massive blooms. Consequently, Si limitation may play a larger role than formerly expected in the Gulf of Lions by controlling diatom growth and limiting the spring bloom in the North Mediterranean Current.

Acknowledgements. The authors would like to thank G. Coustillier for her assistance in building the mooring line and her help on board for immerging and retrieving the sediment traps. We also are deeply grateful to P. Rimmelin for her help on board with collecting the samples, to E. Schaaff for collecting sediment cores and processing them for freeze-drying. We deeply appreciated J. Cotten's help in running the aluminum analysis on our sediment and trap samples. Last, we acknowledge the captains and crews of the coastal vessels Georges Petit and Tethys II, whose help and experience was necessary to carry out this research program. This project was funded by the BioSiCa grant under the PNEC 
program and received support from INSU-CNRS. Work at sea was accomplished on INSU-CNRS research vessels: NO Professeur Georges Petit and NO Tethys II and the authors thank the crew for their help at any occasion.

Edited by: C. Heinze

\section{References}

Auffret, G., Khripounoff, A., and Vangriesheim, A.: Rapid postbloom resuspension in the northeastern Atlantic, Deep-Sea Res. I, 41, 925-939, 1994.

Berger, W. H., Smetacek, V. S., and Wefer, G.: Ocean productivity and paleoproductivity-An overview, in: Productivity of the Ocean: Present and Past, edited by: Berger, W. H., Smetacek, V. S., and Wefer, G., John Wiley \& Sons Ltd, 1-34, 1989.

Boldrin, A., Miserocchi, S., Rabitti, S., Turchetto, M. M., Balboni, V., and Socal, G.: Particulate matter in the southern Adriatic and Ionian Sea: characterisation and downward fluxes, J. Mar. Sys., 33-34, 389-410, 2002.

Buesseler, K. O.: The decoupling of production and particulate export in the surface ocean, Global Biogoechem. Cycles, 12, 297310, 1998.

Brzezinski, M. A.: The Si:C:N ratios of marine diatoms: interspecific variability and the effect of some environmental variables, J. Phycol., 21, 345-357, 1985.

Conley, D. J.: An interlaboratory comparison for the measurement of biogenic silica in sediments, Mar. Chem., 63, 39-48, 1998.

Danovaro, R., Dinet, A., Duineveld, G., and Tselepides A.: Benthic response to particulate fluxes in different trophic environments: a comparison between the Gulf of Lions - Catalan Sea (western-Mediterranean) and the Cretan Sea (easternMediterranean), Prog. Oceanogr., 44, 287-312, 1999.

DeMaster, D. J.: The supply and accumulation of silica in the marine environment, Cosmochim. Acta, 45, 1715-1732, 1981.

Diaz, F.: Evolution saisonnière de la production primaire et des processus d'assimilation - régénération de l'azote dans le golfe du Lion, Estimation d'un bilan de carbone, Approches in situ et modélisation, $\mathrm{PhD}$ thesis, Université de la Méditerranée, AixMarseille II, 2000.

Diaz, F., Raimbault, P., and Conan, P.: Small-scale study of primary productivity during spring in a Mediterranean coastal area (Gulf of Lions), Cont. Shelf Res., 20, 975-996, 2000.

Dugdale, R. C., Wilkerson, F. P., and Minas, H. J.: The role of silicate pump in driving new production, Deep-Sea Res. I, 42, 697-719, 1995.

Durrieu de Madron, X., Abassi, A., Heussner, S., Monaco, A., Aloisi, J. C., Radakovitch, O., Giresse, P., Buscail, R., and Kerhervé, P.: Particulate matter and organic budgets for the Gulf of Lions (NW Mediterranean), Oceanol. Acta, 23, 717-730, 2000.

Fabres, J., Calafat, A., Sanchez-Vidal, A., Canals, M., and Heussner, S.: Composition and spatio-temporal variability of particle fluxes in the Western Alboran Gyre, Mediterranean Sea, J. Mar. Sys., 33-34, 431-456, 2002.

Gardner, W. D., Richardson, M. J., Hinga, K. R., and Biscaye, P. E.: Resuspension measured with sediment traps in a high-energy environment, Earth and Planet. Sci. Let., 66, 262-278, 1983.
Heussner, S., Durrieu de Madron, X., Radakovitch, O., Beaufort, L., Biscaye, P. E., Carbonne, J., Delsaut, N., Etcheber, H., and Monaco, A.: Spatial and temporal patterns of downward particle fluxes on the continental slope of the Bay of Biscay (northeastern Atlantic), Deep-Sea Res. II, 46, 2101-2146, 1999.

Kamatani, A.: Studies on the dissolution of diatomaceous silica as a function of heating, J. Oceanogr. Soc. Jpn., 30, 157-162, 1974.

Kamatani, A. and Oku, O.: Measuring biogenic silica in marine sediments, Mar. Chem., 68, 219-229, 2000.

Kerherve, P., Heussner, S., Charrière, B., Stavrakakis, S., Ferrand, J. L., Monaco, A., and Delsaut, N.: Biogeochemistry and dynamics of settling particle fluxes at the Antikythira Strait (Eastern Mediterranean), Prog. Oceanogr., 44, 651-675, 1999.

Kerhervé, P., Minagawa, M., Heussner, S., and Monaco, A.: Stable isotopes $\left({ }^{13} \mathrm{C} /{ }^{12} \mathrm{C}\right.$ and $\left.{ }^{15} \mathrm{~N} /{ }^{14} \mathrm{~N}\right)$ in settling organic matter of the northwestern Mediterranean Sea: biogeochemical implications, Oceanol. Acta, 24, S77-S85, 2001.

Leblanc, K., Quéguiner, B., Garcia, N., Rimmelin, P., and Raimbault P.: Silicon cycle in the NW Mediterranean Sea: seasonal study of a coastal oligotrophic site, Oceanol. Acta, 26, 339-355, 2003.

Legendre, L. and Le Fèvre, L.: Hydrodynamical singularities as controls of recycled versus export production in oceans, in: Productivity of the Ocean: Present and Past, edited by: Berger, W. H., Smetacek, V. S., and Wefer, G., John Wiley \& Sons Ltd, 4963, 1989.

Liu, K. K., Atkinson, L., Chen, C. T. A., Gao, S., Hall, J., Macdonald, R. W., Talaue MacManus, L., and Quinones, R.: Exploring continental margin carbon fluxes on a global scale, EOS, 81, 641-644, 2000.

Margalef, R.: Life forms of phytoplankton as survival alternatives in an unstable environment, Oceanol. Acta, 1, 493-510, 1978.

Millot, C.: The Gulf of Lions' hydrodynamic, Cont. Shelf Res., 10, 885-894, 1990.

Miserocchi, S., Faganeli, J., Balboni, V., Heussner, S., Monaco, A., and Kerherve, P.: Characteristics and sources of the settling particulate organic matter in the South Adriatic basin, Organic Biogeochem., 30, 411-421, 1999.

Monaco, A., Courp, T., Heussner, S., Carbonne, J., Fowler, S. W., and Deniaux, B.: Seasonality and composition of particle fluxes during ECOMARGE -I, western Gulf of Lions, Cont. Shelf Res., 10, 959-987, 1990.

Monaco, A., Durrieu de Madron, X., Radakovitch, O., Heussner, S., and Carbonne, J.: Origin and variability of downward biogeochemical fluxes on the Rhône continental margin (NW Mediterranean), Deep-Sea Res. I, 46, 1483-1511, 1999.

Mortlock, R. A. and Froelich, P. N.: A simple method for the rapid determination of biogenic opal in pelagic marine sediments, Deep-Sea Res., 36, 1415-1426, 1989.

Pondaven, P., Ragueneau, O., Tréguer, P., Hauvespre, A., Dezileau, L., and Reyss, J. L.: Resolving the 'opal paradox' in the Southern Ocean, Nature, 405, 168-172, 2000.

Ragueneau, O., Tréguer, P., Leynaert, A., Anderson, R. F., Brzezinski, M. A., Demaster, D. J., Dugdale, R. C., Dymond, J., Fisher, G., François, R., Heinze, C., Maier-Reimer, E., Martin-Jézéquel, V., Nelson, D. M., and Quéguiner, B.: A review of the Si cycle in the modern ocean: recent progress and missing gaps in the application of biogenic opal as a paleoproductivity proxy, Global and Planetary Change, 26, 317-365, 2000. 
Ragueneau, O., Dittert, N., Pondaven, P., Tréguer, P., and Corrin, L.: $\mathrm{Si} / \mathrm{C}$ decoupling in the world ocean: is the Southern Ocean different?, Deep-Sea Res. II, 49, 3127-3154, 2002.

Raimbault, P., Pouvesle, W., and Boudjellal, B.: A semi-automatic, wet-oxydation method for simultaneous determination of particulate carbon, nitrogen and phosphorus collected on filters, Mar. Ecol. Progr. Ser., 180, 289-295, 1999.

Smetacek, V. S.: Role of sinking in diatom life-history cycles: ecological, evolutionary and geological significance, Mar. Biol., 84, 239-251, 1985.
Stavrakakis, S., Chronis, G., Tselepides, A., Heussner, S., Monaco, A., and Abassi, A.: Downward fluxes of settling particles in the deep Cretan Sea (NE Mediterranean), Progr. Oceanogr., 46, 217 240, 2000.

Tréguer, P., Nelson, D. M., Van Bennekom, A. J., Demaster, D. J., Quéguiner, B., and Leynaert, A.: The silica budget of the World Ocean: a re-estimate, Science, 268, 375-379, 1995.

Wollast, R.: The coastal organic carbon cycle: fluxes, sources and sinks, in: Ocean margin processes in global change, Mantoura R.F.C., edited by: Martin, J. M. and Wollast, R., John Wiley \& Sons Ltd, 365-381, 1991. 